\title{
Inhibitory Effects of Essential Oil from Zanthoxylum coreanum Nakai on Melanin Production: Protection Against Re-Pigmentation after Laser Treatment
}

\author{
Ye-Na Kim ${ }^{1, *}$ \\ Mi-Jin Park ${ }^{2, *}$ \\ Zhenlong Zheng 1,3 \\ Sung-Suk Lee ${ }^{2}$ \\ Kwang $\mathrm{Ho} \mathrm{Yoo}^{1}$ \\ Heesu Kim ${ }^{1}$
}

\footnotetext{
${ }^{1}$ Department of Dermatology and Cutaneous Biology Research Center, International St. Mary's Hospital, Catholic Kwandong University College of Medicine, Incheon, Korea

${ }^{2}$ Division of Wood Chemistry, Department of Forest Products, National Institute of Forest Science, Seoul, Korea

${ }^{3}$ Department of Dermatology, Yanbian University Hospital, Yanji, China
}

\begin{abstract}
Introduction
Zanthoxylum coreanum Nakai (ZCN) is a Korean lime tree that only grows in the southernmost areas of Korea, including Jeju Island. It has been used as both an herb in food and medicines for curing stomachache and skin disorders in Oriental medicine. Nevertheless, studies have yet to investigate the effects of ZCN on melanogenesis in the skin. This study was conducted to investigate the effects of ZCN essential oil on melanogenesis.
\end{abstract}

\section{Materials and Methods}

The essential oil was extracted from the fruits of ZCN by hydro-distillation at the National Institute of Forest Science. The viability of human dermal fibroblasts and B16F10 cells was determined by cell counting kit-8 assay. Mushroom tyrosinase activity assay and melanin assay were performed on B16F10 cells to evaluate the inhibitory effects of ZCN essential oil on melanogenesis. Also, gas chromatography (GC)-mass spectrometry (MS) analysis was performed to detect the components of ZCN essential oil.

\section{Results}

The ZCN essential oil inhibited human dermal fibroblast cell proliferation with an $I C_{50}$ value of $0.06877 \%$ and $B 16 F 10$ cell proliferation with an $I C_{50}$ value of $0.01104 \%$. Treatment with $\mathrm{ZCN}$ essential oil reduced tyrosinase activity in B16F10 cells, and the anti-melanogenic property was positively correlated with the concentration of ZCN essential oil. GC-MS analysis of ZCN essential oil identified $\beta$-Ocimene (24.48\%), (-)- $\alpha$-pinene (16.56\%), 4-carvomenthenol (11.61\%), and sabinene $(10.81 \%)$ as the most abundant components.

\section{Discussion}

Our study showed that essential oil extracted from ZCN obtained from Jeju Island can be safely applied to the skin and may be useful as a potential skin-whitening ingredient in cosmeceuticals to prevent re-pigmentation or post-inflammatory hyperpigmentation after laser treatment.

\section{Key words}

Zanthoxylum coreanum Nakai; Melanogenesis; B16F10 cells; Whitening

*The first two authors contributed equally to this work.

(C) Korean Society for Laser Medicine and Surgery

(c) This is an open access article distributed under the terms of the Creative Commons Attribution NonCommercial License (http://creativecommons.org/ licenses/by-nc/4.0) which permits unrestricted noncommercial use, distribution, and reproduction in any medium, provided the original work is properly cited. 


\section{INTRODUCTION}

Melanocytes elicit melanin pigmentation in the skin and hair as a protective reaction upon ultraviolet radiationinduced skin injury via a process called melanogenesis. Overexposure to ultraviolet radiation causes not only cosmetic skin problems, including hyperpigmentary disorders such as melasma and freckles, and aged skin, but also medicinal problems, such as skin cancers. ${ }^{1-3}$

Melanogenic enzymes, such as tyrosinase, tyrosinaserelated protein (TRP)-1, and TRP-2, typically control melanin pigmentation in melanocytes. ${ }^{4}$ Although various signaling pathways are known to regulate melanogenesis, mitogen-activated protein kinase (MAPKs) signaling pathways have been found to lead to a reduction in melanin synthesis in mouse melanocyte cells. ${ }^{5}$ Because tyrosinase is the main catalytic enzyme in the rate-limiting phase of melanogenesis, inducing the hydroxylation of tyrosine to 3,4-dihydroxyphenylalanine (DOPA) and the oxidation of DOPA to dopaquinone, ${ }^{6}$ it is usually the primary target via which to inhibit pigmentation synthesis.

Natural ingredients that inhibit the activity of tyrosinase could be useful as depigmentation compounds. Zanthoxylum (Rutaceae) species have been used for centuries as sources of spices in Asian cuisine and traditional Asian medicine. ${ }^{7-9}$ The root bark and stems of one species within this genus, Z. schinifolium, have been reported to exhibit antiviral activity against hepatitis $B$ virus. ${ }^{10}$ Zanthoxylum coreanum Nakai (ZCN), one of four Zanthoxylum (Rutaceae) species original to Korea, has been used as herbs in food and as traditional medicines for treating stomachache, helminths, and skin disorders. ${ }^{11,12}$ ZCN grows in limited areas of Korea, Jeju Island and the Southern coast of Korea. Despite the traditional usages of ZCN, the observed depigmentation activity of essential oil extracted therefrom has not yet been thoroughly investigated. In the present study, we aimed to evaluate the antimelanogenic function of essential oil extracted from the fruits of ZCN in mouse B16F10 cells.

\section{MATERIALS AND METHODS}

\section{Plant material and extraction procedure}

The fruits of ZCN were collected from an experimental forest maintained by the National Institute of Forest Science located on Jeju Island, Republic of Korea, in August 2017. Taxonomical identifications were established by ecologist Dr. Hwa-Ja Hyeon, Subtropical Forest Research Center, National Institute of Forest Science at a warm temperate. The voucher specimen code is WTFRC

\section{5.}

The collected fruits of ZCN were hydro-distillated at atmospheric pressure, using a Clevenger-type apparatus. A 10- $L$ round-bottom flask containing $2099.8 \mathrm{~g}$ of fruit was placed on a heating mantle. In this flask, the fruits were mixed in $5 \mathrm{~L}$ of distilled water. Then, the flask was connected to a Clevenger-type apparatus. Essential oil was extracted from the fruits of ZCN for $14 \mathrm{~h}$. The collected essential oil was dried over anhydrous sodium sulphate and filtered through a 0.45 -um membrane disk filter. The obtained oil was transferred to sealed dark vials and stored at $4^{\circ} \mathrm{C}$ for further analysis. The essential oil content was determined on the basis of oven dried matter, and measurements were carried out in triplicate. The yield (\%) of essential oil was calculated using the following formula:

Essential oil yield $(\%)=\frac{\text { mass of essential oil obtained }(\mathrm{g})}{\text { mass of oven dry natter }(\mathrm{g})} \times 100$

\section{Gas chromatography-mass spectrometry analysis}

Coupled gas chromatography (GC)-mass spectrometry (MS) analysis was performed on a Thermo Scientific Model ISQ LT equipped with both a flame ionization detector (FID) and a mass spectrometer. GC-MS analysis solution was prepared by dissolving $4 \mu \mathrm{l}$ of oil in $1.0 \mathrm{ml}$ of dichloromethane solution (containing 100 ppm methyl undecanoate); $1 \mu$ l was injected for analysis. A VF-5MS GC column $160 \mathrm{~m} \times 0.25 \mathrm{~mm} \times 0.25 \mu \mathrm{m}$ film thickness; Agilent Technologies, Santa Clara, CA, USAl was used. As the carrier gas, helium was applied at a constant flow rate of $1.0 \mathrm{~mL} /$ min. The injection temperature was $250^{\circ} \mathrm{C}$, with a split ration of 1:20. The oven temperature was maintained at $50^{\circ} \mathrm{C}$ for $5 \mathrm{~min}$, increased by $10^{\circ} \mathrm{C} / \mathrm{min}$ to $65^{\circ} \mathrm{C}$ and held for $30 \mathrm{~min}$, increased by $5^{\circ} \mathrm{C} / \mathrm{min}$ to $120^{\circ} \mathrm{C}$ and held for 10 min, increased by $5^{\circ} \mathrm{C} / \mathrm{min}$ to $210^{\circ} \mathrm{C}$ and held for $10 \mathrm{~min}$, and finally increased by $20^{\circ} \mathrm{C} / \mathrm{min}$ to $325^{\circ} \mathrm{C}$ and held for $10 \mathrm{~min}$. For FID detection, temperature was set to $300^{\circ} \mathrm{C}$, with the air flow set to $350.0 \mathrm{ml} / \mathrm{min}$, hydrogen flow to 35.0 $\mathrm{ml} / \mathrm{min}$, and make-up gas (helium) flow to $40.0 \mathrm{ml} / \mathrm{min}$. Mass interface temperature was $250^{\circ} \mathrm{C}$, and ion source temperature was $250^{\circ} \mathrm{C}$. Mass scan data were acquired in the El mode at a scan time rate of $0.2 \mathrm{sec}$, with a scan range from 35 amu to $550 \mathrm{amu}$.

The identification of peaks was performed by comparing the average mass spectrum of peaks with an electronic library database (NIST/EPA/NIH Mass Spectral Library, version $2.0 \mathrm{~g}$ ). In addition, Kovats index (KI) was calculated by injection of an n-alkane (C7-C30) standard and was described as supplementary data for peak iden- 
tification.

\section{Cell culture}

The B16F10 murine melanoma cells (CRL-6475) were purchased from the American Type Culture Collection (Rockville, MD, USA). The cells were cultured in RPMI 1640 with L-glutamine medium supplemented with 10\% fetal bovine serum (FBS) and 1\% penicillin-streptomycin (PS) in $5 \% \mathrm{CO}_{2}$ at $37^{\circ} \mathrm{C}$. Cells were passaged every 3 days until a maximal passage number of 20 was achieved. Human dermal fibroblast (HDF) cells (CC-2509\&CC-2511) were purchased (Lonza, Basel, Switzerland) and were incubated in fibroblast growth medium-2 (FGM ${ }^{\mathrm{T} M}-2$; Lonza) containing 2\% FBS, 0.1\% insulin, 0.1\% hFGF, 0.1\% GA1000 , and $1 \% \mathrm{PS}$ at $37^{\circ} \mathrm{C}$ in a $5 \% \mathrm{CO}_{2}$ incubator.

\section{Cell viability test}

B16F10 cells and HDFs were seeded in 96-well plates. After $24 \mathrm{~h}$ of incubation, the media was washed with DPBS and replaced with media containing essential oil of ZCN diluted to various concentrations. After $24 \mathrm{~h}$, the media was washed with DPBS and replaced with media containing 10\% Cell Counting Kit (CCK)-8 solution (Dojindo Molecular Technology Inc., Tokyo, Japan). The cells were then incubated at room temperature and measured at $450 \mathrm{~nm}$ using a microplate reader (SoftMax Pro 5; Molecular Devices, CA, USA).

\section{Mushroom tyrosinase activity assay}

Mushroom tyrosinase activity assay was performed as previously described, with slight modification. ${ }^{13}$ Briefly, mushroom tyrosinase activity was assessed according to DOPA oxidase activity. A total of $100 \mu \mathrm{l}$ of $0.1 \mathrm{M}$ sodium phosphate buffer (pH 6.5) containing kojic acid (SigmaAldrich Inc; St Louis, MO, USA), L-ascorbic acid (SigmaAldrich Inc.), and essential oil of ZCN was added to $30 \mu \mathrm{l}$ of mushroom tyrosinase (1000 U/ml) (Sigma-Aldrich Inc.) in each well. Then $10 \mu \mathrm{l}$ of $12 \mathrm{mM}$ L-DOPA was added. Absorbance were measured every $10 \mathrm{~min}$ for at least $1 \mathrm{~h}$ at $490 \mathrm{~nm}$ using a microplate reader at $37^{\circ} \mathrm{C}$.

\section{Melanin content assay}

B16F10 cells characteristically release melanin. The release of melanin was assessed as previously described, ${ }^{14}$ with slight modification. Cells were seeded in six-well plates. B16F10 cells were treated with ZCN essential oil and $100 \mu \mathrm{l}$ of $12 \mathrm{mM}$ L-DOPA for $24 \mathrm{~h}$, after which cell pellets were dissolved in $1 \mathrm{~mol} / \mathrm{L} \mathrm{NaOH}$ for $1 \mathrm{~h}$ at $60^{\circ} \mathrm{C}$. Relative melanin content was determined by absorbance at $490 \mathrm{~nm}$ on a microplate reader. Standard curves were prepared in triplicate for each batch, based on synthetic melanin (0-250 g/mL). Melanin production was calculated by normalizing total melanin readings with protein content, expressed as percentages of control values.

\section{Statistical analysis}

Statistical analyses were performed using SPSS 18.0 (SPSS Inc, Chicago, IL, USA). All experiments were conducted at least three times. Results are presented as means $( \pm)$ standard deviations. Data were analyzed by one-way ANOVA, followed by Tukey's multiple tests. $P$ values of $p<0.05\left(^{*}\right), p<0.01\left(^{* *}\right)$, and $p<0.001\left(^{* * *}\right)$ were considered statistically significant.

\section{RESULTS}

\section{Chemical profiles of essential oil extracted from ZCN by GC-MS}

The yield of the essential oil from ZCN was about 2.1\%. The chemical compositions of ZCN are shown in Table 1. In total, 37 constituents were identified from the essential oil of ZCN fruit. $\beta$-Ocimene was the predominant component, accounting for $24.48 \%$ of the content, followed by (-)- $\alpha$-pinene (16.56\%), 4-carvomenthenol (11.61\%), sabinene (10.81\%), linalool (10.09\%), o-cymene (3.56\%), $\beta$ -phellandrene (3.15\%), limonene (2.63.\%), and $\alpha$-terpineol $(1.74 \%)$

\section{Effect of essential oil extracted from ZCN on HDF and B16F10 cell viability}

The cytotoxicity of essential oil from ZCN on mouse cells was evaluated using CCK-8 assay and CCK-8 kits (Dojindo, Tokyo, Japan). Human dermal fibroblasts and B16F10 cells were treated with essential oil extracted from the fruits of $\mathrm{ZCN}$ at concentrations ranging from $0 \%-10^{-4} \%$ for $24 \mathrm{~h}$ in serum-free media. Each condition was experimented in triplicate, and IC50 values were calculated from curves using a best fit line. As shown in Fig. 1, the IC50 values of essential oil extracted from ZCN on HDF and B16F10 cells were $0.06877 \%$ and $0.01104 \%$, respectively. Accordingly, the IC50 value (0.01104\%) for ZCN essential oil on B16F10 cells was used as reference concentration in subsequent experiments.

\section{Effect of essential oil extracted from ZCN on me- lanogenesis in B16F10 cells}

To determine whether ZCN inhibits melanogenesis in B16F10 cells, melanin content was measured in B16F10 cells after 2 days of treatment with essential oil from ZCN 
Table 1. Gas chromatography-mass spectrometry analysis of essential oil extracted from Zanthoxylum coreanum Nakai

\begin{tabular}{|c|c|c|c|c|}
\hline RT & Constituent & Area \% & $\mathrm{KI}^{\mathrm{a}}$ & Identification \\
\hline 19.36 & $\alpha$-Thujene & 0.59 & 917.77 & $\mathrm{MS}, \mathrm{KI}$ \\
\hline 20.17 & (-)- $\alpha$-Pinene & 16.56 & 923.62 & $\mathrm{MS}, \mathrm{KI}$ \\
\hline 22.22 & Camphene & 0.06 & 938.43 & $\mathrm{MS}, \mathrm{KI}$ \\
\hline 25.24 & Sabinene & 10.81 & 960.24 & $\mathrm{MS}, \mathrm{KI}$ \\
\hline 26.01 & $\beta$-Pinene & 0.30 & 965.80 & $\mathrm{MS}, \mathrm{KI}$ \\
\hline 27.98 & $\beta$-Myrcene & 0.32 & 980.03 & $\mathrm{MS}, \mathrm{KI}$ \\
\hline 34.76 & o-Cymene & 3.56 & 1029.00 & $\mathrm{MS}, \mathrm{KI}$ \\
\hline 35.62 & Limonene & 2.63 & 1035.21 & $\mathrm{MS}, \mathrm{KI}$ \\
\hline 35.91 & $\beta$-Phellandrene & 3.15 & 1037.31 & $\mathrm{MS}, \mathrm{KI}$ \\
\hline 37.39 & $\beta$-Ocimene & 24.48 & 1048.00 & $\mathrm{MS}, \mathrm{KI}$ \\
\hline 39.15 & $\alpha$-0cimene & 2.40 & 1060.71 & $\mathrm{MS}, \mathrm{KI}$ \\
\hline 40.82 & $\gamma$-Terpinene & 0.17 & 1072.77 & $\mathrm{MS}, \mathrm{KI}$ \\
\hline 42.21 & Sabinene hydrate & 0.07 & 1082.81 & $\mathrm{MS}, \mathrm{KI}$ \\
\hline 42.62 & $\alpha$-Pinene oxide & 0.39 & 1085.77 & $\mathrm{MS}, \mathrm{KI}$ \\
\hline 43.56 & Terpinolene & 0.07 & 1092.56 & $\mathrm{MS}, \mathrm{KI}$ \\
\hline 44.27 & $\begin{array}{l}\text { 3-Methyl-2-(3-methylbut- } \\
\text { 2-enyl)-furan }\end{array}$ & 0.15 & 1097.69 & $\mathrm{MS}, \mathrm{KI}$ \\
\hline 44.80 & Linalool & 10.09 & 1103.31 & $\mathrm{MS}, \mathrm{KI}$ \\
\hline 45.95 & Camphor & 0.07 & 1121.42 & $\mathrm{MS}, \mathrm{KI}$ \\
\hline 46.52 & cis- $\rho$-Menth-2-en-1-ol & 0.48 & 1130.39 & $\mathrm{MS}, \mathrm{KI}$ \\
\hline 46.70 & (4E,6Z)-Alloocimene & 0.69 & 1133.23 & $\mathrm{MS}, \mathrm{KI}$ \\
\hline 47.52 & $\beta$-Pinene oxide & 0.18 & 1146.14 & $\mathrm{MS}, \mathrm{KI}$ \\
\hline 47.69 & p-Menth-3-en-1-ol & 0.46 & 1148.82 & $\mathrm{MS}, \mathrm{KI}$ \\
\hline 50.04 & 4-Carvomenthenol & 11.61 & 1185.83 & $\mathrm{MS}, \mathrm{KI}$ \\
\hline 50.65 & $\begin{array}{l}\text { 4-Isopropyl-2-cyclohexe- } \\
\text { none }\end{array}$ & 0.64 & 1195.43 & $\mathrm{MS}, \mathrm{KI}$ \\
\hline 51.07 & $\alpha$-Terpineol & 1.74 & 1201.69 & $\mathrm{MS}, \mathrm{KI}$ \\
\hline 52.09 & p-Penth-1-en-3-ol,cis-(+)- & 0.26 & 1217.95 & $\mathrm{MS}, \mathrm{KI}$ \\
\hline 53.14 & Ascaridole & 0.13 & 1228.61 & $\mathrm{MS}, \mathrm{KI}$ \\
\hline 57.77 & Bornyl acetate & 0.05 & 1288.82 & $\mathrm{MS}, \mathrm{KI}$ \\
\hline 58.70 & Limonene dioxide & 0.02 & 1301.19 & $\mathrm{MS}, \mathrm{KI}$ \\
\hline 64.33 & $\beta$-Elemene & 0.10 & 1396.61 & $\mathrm{MS}, \mathrm{KI}$ \\
\hline 67.00 & Humulene & 0.02 & 1461.44 & $\mathrm{MS}, \mathrm{KI}$ \\
\hline 67.51 & $\alpha$-Farnesene & 0.20 & 1461.44 & $\mathrm{MS}, \mathrm{KI}$ \\
\hline 68.18 & $\alpha$-Muurolene & 0.03 & 1490.80 & $\mathrm{MS}, \mathrm{KI}$ \\
\hline 69.55 & $(+)-\delta$-Cadinene & 0.19 & 1531.75 & $\mathrm{MS}, \mathrm{KI}$ \\
\hline 71.79 & $\beta$-Caryophyllene oxide & 0.45 & 1603.38 & $\mathrm{MS}, \mathrm{KI}$ \\
\hline 73.48 & $\tau$-Muurolol & 0.18 & 1666.92 & $\mathrm{MS}, \mathrm{KI}$ \\
\hline 73.80 & (-)- $\alpha$-Cadinol & 0.49 & 1678.95 & $\mathrm{MS}, \mathrm{KI}$ \\
\hline
\end{tabular}

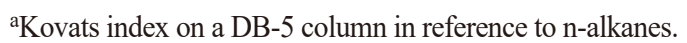
RT, retention time; MS, NIST/EPA/NIH Mass Spectral Library; KI, Kovats index.

at concentrations of $0.00125 \%-0.01 \%$. Kojic acid and Lascorbic acid, well-known tyrosinase inhibitors, were used as positive controls, as previously described. ${ }^{14,15}$ B16F10 cells treated with ZCN showed reduced melanin production at the concentrations of $0.00125 \%-0.01 \%$, although a significant positive correlation between essential oil concentration and melanin production was not observed (Fig. 2A). Interestingly, decreases in melanin production upon treatment with ZCN essential oil were similar to those achieved with treatment with $0.5 \mathrm{mM}$ kojic acid.

Tyrosinase is known to be the major regulator of melanogenesis via an enzymatic cascade, ${ }^{16}$ and various whitening ingredients applied to the skin have been developed to directly inhibit tyrosinase. ${ }^{17}$ Therefore, we measured the activity of mushroom tyrosinase in a cell-free system in order to determine the direct inhibitory effects of essential oil extracted from ZCN on tyrosinase. Both $0.5 \mathrm{mM}$ kojic acid and $0.25 \mathrm{mM} \mathrm{L-ascorbic} \mathrm{acid} \mathrm{significantly} \mathrm{inhib-}$ ited tyrosinase activity. Similarly, essential oil extracted from ZCN at concentrations of 0.005\%-0.04\% elicited a significant reduction in mushroom tyrosinase activity, compared to control (Fig. 2B). Also, concentrations of essential oil from ZCN showed a positive correlation with the inhibition of tyrosinase. These results indicated that the inhibitory effect of ZCN on melanogenesis is due to the direct inhibition of tyrosinase. Even though ZCN essential oil concentrations of $0.04 \%$ and $0.02 \%$ were a little higher than the reference IC50 value $(0.01104 \%)$ of cell viability for B16F10 cells, a cytotoxic effect of the essential oil was not observed at these concentrations during the tyrosinase activity assay. We speculate that this may be because the reaction time in the tyrosinase activity assay was shorter than those for the melanin content assay and cell viability tests.

\section{DISCUSSION}

Pigmentary disorders, including melasma, lentigo, and freckles, are not easy to treat in Asian patients using light, laser, and radiofrequency energy devices because of higher grade Fitzpatrick skin types and a tendency for hyperpigmentation upon sun exposure. ${ }^{13}$ After treating pigmentation with energy devices, Asian patients tend to experience side effects of hyperpigmentation or postinflammatory hyperpigmentation. ${ }^{18}$ For these reasons, many Asian patients rely on the use of whitening ingredients in cosmeceutical and medicinal products to treat hyperpigmented skin. However, some of these products include mercury and hydroquinone and elicit unpredictable side effects and toxicity. ${ }^{19}$ Even though many studies have been performed to identify safe and effective whitening substances from nature, natural ingredients with antimelanogenic properties that can inhibit tyrosinase, TRP1, and TRP-2 have yet to be discovered.

Grown in Korea, ZCN is morphologically similar to $Z$. schinifolium Siebold et Zuccarini and Z. piperitum De Candolle. ${ }^{20}$ Although they are morphological similar, their chemical profiles and physiological functions are differ- 
A

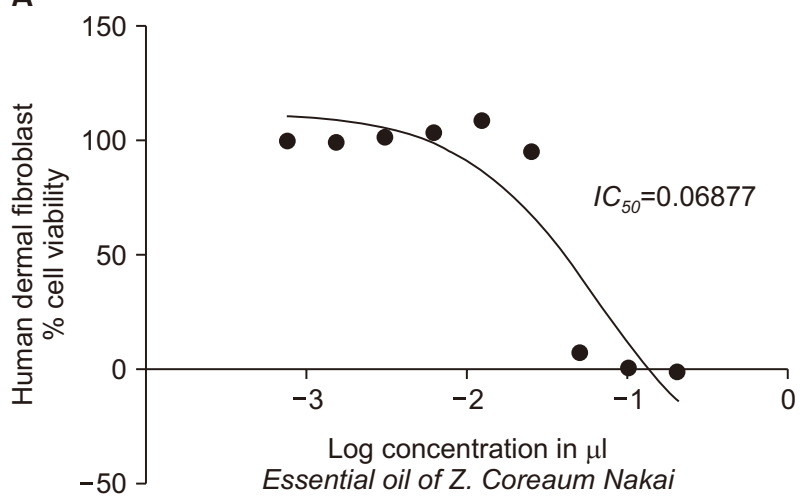

B

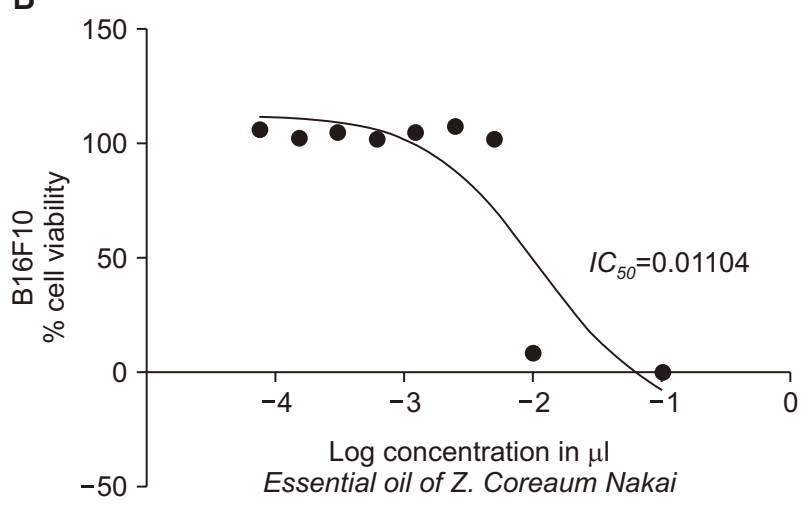

Fig. 1. Effects of essential oil extracted from Zanthoxylum coreanum Nakai $(\mathrm{ZCN})$ on the viability of human dermal fibroblasts and mouse cells. (A) Human dermal fibroblasts and (B) B16F10 mouse cells were treated with essential oil extracted from the fruits of ZCN, at concentrations ranging from $0-100 \%$, for $24 \mathrm{~h}$ in serum-free media. Cell viability was assessed using Cell Counting Kit- 8 assays. Each experiment was performed in triplicate, and IC50 values were calculated from curves using the best fit line.
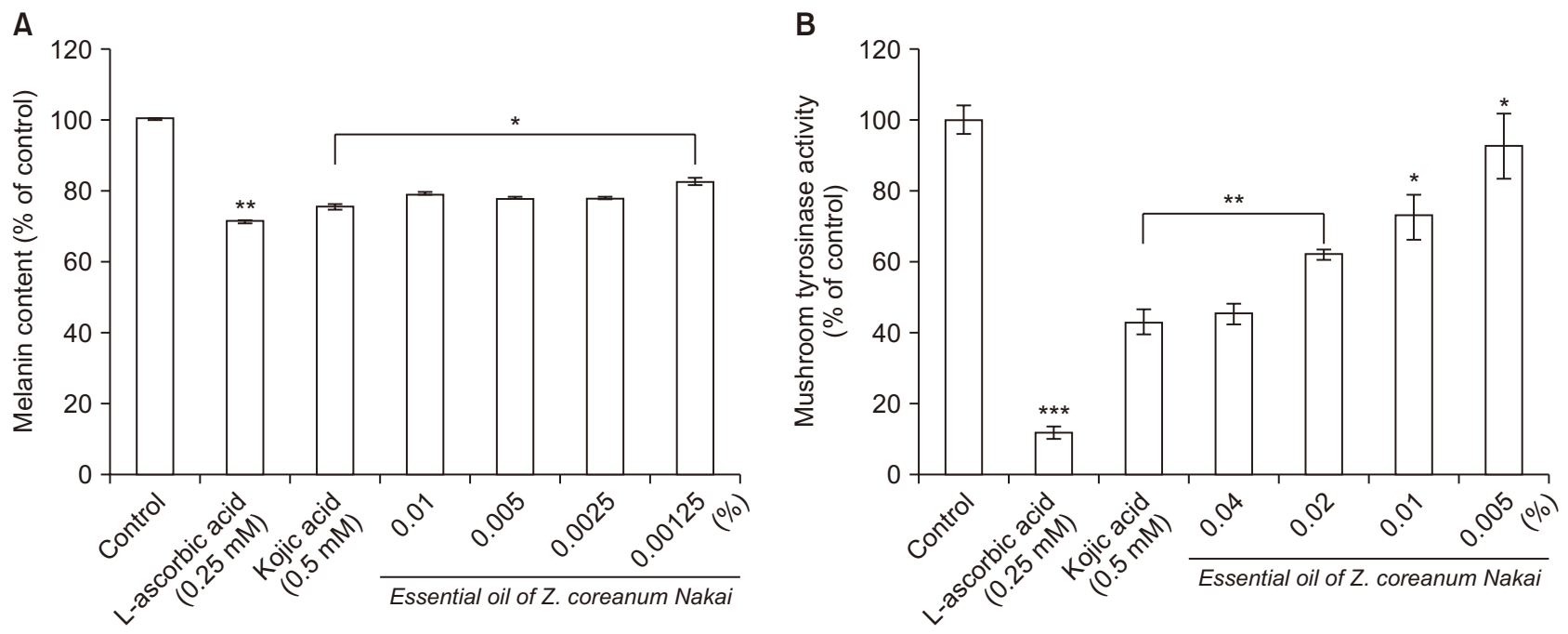

Fig. 2. Effects of essential oil extracted from ZCN on melanogenesis in B16F10 cells. B16F10 cells were treated with ZCN (0.005-0.04\%), L-ascorbic acid $(0.25 \mathrm{mM})$, and kojic acid $(0.5 \mathrm{mM})$. (A) Melanin content and (B) mushroom tyrosinase activity in B16F10 cells were measured as described in the Materials and methods. Each experiment was performed in triplicate, and the data represent means $\pm \mathrm{SD} . p<0.05(*), p<0.01(* *)$, and $p<0.005(* * *)$ versus non-treated control (A) or L-DOPA-treated control (B). *Data are presented as estimated means \pm standard deviations.

ent. Based on genetic analysis Z. piperitum and Z. coreanum can be classified to a single group: $Z$. schinifolium and Z. piperitum belong to Zanthoxylum Pericarpium. ${ }^{20}$ Recently, marker nucleotides for ZCN were detected upon analysis of rDNA-ITS DNA barcode regions in three Zanthoxylum species grown in Korea. ${ }^{20}$ In comparison of three Zanthoxylum ITS2 sequences, 16, six, and four species-specific nucleotides were identified to distinguish among Z. schinifolium, Z. piperitum, and Z. coreanum, respectively.

In Korea, Zanthoxylum has been used for many medical purposes. ${ }^{7-9,21,22}$ In ancient Korean medical litera- ture, researchers described that $Z$. coreanum could be crudely used to treat various medical conditions, such as stomachache, sore throat, toothache, limb pain, rheumatoid arthritis, nasal sinusitis, ozena, meno-xenia, and skin disorders. ${ }^{9,11,20}$ Despite the use of ZCN in traditional medicine, the pharmaceutical mechanisms of its fruits and leaves have not been thoroughly investigated for use in medicinal purposes. Furthermore, other than archaic descriptions of applying ZCN to the skin to alleviate itching and to promote wound healing, the effects of ZCN on the skin have not been demonstrated via in vitro or in vivo experiments. ${ }^{20}$ 
Accordingly, we performed the present study to evaluate the effects ZCN essential oil on pigmentation in the skin. Our in vitro results indicated that essential oil extracted from the fruits of ZCN by hydro-distillation inhibit melanogenesis in mouse B16F10 cells by reducing the action of tyrosinase. The anti-melanogenic properties thereof showed a positive correlation with the concentration of ZCN essential oil applied. With a concentration near the IC50 value on cell viability test, treatment with ZCN essential oil reduced melanin production in cells to levels similar to those obtained with kojic acid treatment. Meanwhile, in vitro scratch assay demonstrated that the essential oil of ZCN does not affect the proliferation of human dermal fibroblasts, compared with control group (data not shown). Also, the major components of essential oil extracted from ZCN, including $\beta$-Ocimene, $(-)-\alpha$ -pinene, 4-carvomenthenol, and sabinene, have been reported to be helpful to inhibiting tyrosinase activity. ${ }^{23}$ Thus, the essential oil of ZCN could be a good candidate for skin whitening compounds. ${ }^{23-25}$

In conclusion, this study newly demonstrated that essential oil extracted from the fruits of ZCN obtained from Jeju Island, Republic of Korea by hydro-distillation has inhibitory effects on melanin synthesis in B16F10 cells. We noted that decreased melanin production via inhibition of tyrosinase was dose dependent without critical cytotoxicity in B16F10 cells. The concentrations that elicited an inhibitory effect on melanogenesis appeared to be safe for both human dermal fibroblasts and mouse melanoma B16F10 cells. Accordingly, we deemed that ZCN essential oil could be useful as a potential de-pigmentation ingredient in cosmeceuticals to protect against un-wanted effects, including re-pigmentation or post-inflammatory hyperpigmentation, after laser treatment for pigmentary disorders without scar formation. In the future, further study with 3D artificial skin will be needed to evaluate the safety of formulations containing essential oil of ZCN designed as whitening cosmeceuticals for preventing the side-effects described above after laser treatment.

\section{ACKNOWLEDGEMENTS}

This study was carried out with support from the Forest Science Technology Program (Project No. FP0900-201601) funded by the National Institute of Forest Science and R\&D Program for Forest Science Technology (Project No. 2017033A00-1819-BA01) provided by Korea Forest Service (Korea Forestry Promotion Institute). We would like to thank Anthony Thomas Milliken, ELS, at Editing Synthase (http://editingsynthase.com) for his help with the editing of this manuscript.

\section{CONFLICT OF INTEREST}

The authors declare no conflicts of interest.

\section{REFERENCES}

1. D'Mello SA, Finlay GJ, Baguley BC, Askarian-Amiri ME. Signaling pathways in melanogenesis. Int J Mol Sci 2016;17:1144.

2. Sklar LR, Almutawa F, Lim HW, Hamzavi I. Effects of ultraviolet radiation, visible light, and infrared radiation on erythema and pigmentation: a review. Photochem Photobiol Sci 2013;12:5464.

3. Ichihashi M, Ando H. The maximal cumulative solar UVB dose allowed to maintain healthy and young skin and prevent premature photoaging. Exp Dermatol 2014;23:S43-6.

4. Huang HC, Hsieh WY, Niu YL, Chang TM. Inhibitory effects of adlay extract on melanin production and cellular oxygen stress in B16F10 melanoma cells. Int J Mol Sci 2014;15:16665-79.

5. Han JS, Sung JH, Lee SK. Antimelanogenesis activity of hydrolyzed ginseng extract (GINST) via inhibition of JNK mitogen-activated protein kinase in B16F10 cells. J Food Sci 2016;81:2085-92.

6. Camacho-Hübner A, Beermann F. [Cellular and molecular features of mammalian pigmentation--tyrosinase and TRP]. Pathol Biol (Paris) 2000;48:577-83. in French.

7. Bryant BP, Mezine I. Alkylamides that produce tingling paresthesia activate tactile and thermal trigeminal neurons. Brain Res 1999;842:452-60.

8. Shibata C, Sasaki I, Naito H, Ueno T, Matsuno S. The herbal medicine Dai-Kenchu-Tou stimulates upper gut motility through cholinergic and 5-hydroxytryptamine 3 receptors in conscious dogs. Surgery 1999;126:918-24.

9. Cho MG, Chang CS, Chae YA. Variation of volatile composition in the leaf of Zanthoxylum schinofolium siebold et zucc. And Zanthoxylum piperitum DC. Korean J Med Crop Sci 2002;10:16266.

10. Chang CT, Doong SL, Tsai IL, Chen IS. Coumarins and antiHBV constituents from Zanthoxylum schinifolium. Phytochem 1997:45:1419-22.

11. Kim CM, Yook CS, Shin ET. Studies on the conatituents of Zanthoxylum coreanum Nakai. Korean J Pharmacol 1987;18:18083.

12. Choi HJ, Song JH, Kwon DH, Baek SH, Ahn YJ. Antiviral activity of Zanthoxylum species against Influenza virus. Korean J Med Crop Sci 2008; 16:273-8.

13. Oh CT, Kwon TR, Jang YJ, Yoo KH, Kim BJ, Kim H. Inhibitory effects of Stichopus japonicus extract on melanogenesis of mouse cells via ERK phosphorylation. Mol Med Rep 
2017;16:1079-86.

14. Niu C, Yin L, Aisa HA. Novel furocoumarin derivatives stimulate melanogenesis in B16 Melanoma cells by up-regulation of MITF and TYR family via Akt/GSK3B/ $\beta$-catenin signaling pathways. Int J Mol Sci 2018;19:746.

15. Cabanes J, Chazarra S, Garcia-Carmona F. Kojic acid, a cosmetic skin whitening agent, is a slow-binding inhibitor of catecholase activity of tyrosinase. J Pharm Pharmacol 1994;46:9825.

16. Casanola-Martin GM, Le-Thi-Thu H, Marrero-Ponce Y, CastilloGarit JA, Torrens F, Rescigno A, et al. Tyrosinase enzyme: 1. an overview on a pharmacological target. Curr Top Med Chem 2014;14:1494-501.

17. Smit N, Vicanova J, Pavel S. The hunt for natural skin whitening agents. Int J Mol Sci 2009;10:5326-49.

18. Kim MS, Bang SH, Kim JH, Shin HJ, Choi JH, Chang SE. Tranexamic acid diminishes laser-induced melanogenesis. Ann Dermatol 2015;27:250-6.

19. Desmedt B, Rogiers V, Courselle P, De Beer JO, De Paepe K, Deconinck E. Development and validation of a fast chromatographic method for screening and quantification of legal and illegal skin whitening agents. J Pharm Biomed Anal 2013;83:82-
8.

20. Kim WJ, Ji YU, Lee YM, Kang YM, Choi GY, Moon BC. Development of molecular markers for the authentication of Zanthoxyli pericarpium by the analysis of rDNA-ITS DNA barcode regions. Korea J Herbology 2015;30:41-7.

21. Choi HJ. Evaluation of antiviral activity of Zanthoxylum species against Picornaviruses. Osong Public Health Res Perspect 2016;7:400-3.

22. Medhi K, Deka M, Bhau BS. The genus Zanthoxylum - a stockpile of biological and ethnomedicinal properties. Sci Rep 2013;2:697.

23. Chao WW, Su CC, Peng HY, Chou ST. Melaleuca quinquenervia essential oil inhibits $\alpha$-melanocyte-stimulating hormoneinduced melanin production and oxidative stress in B16 melanoma cells. Phytomedicine 2017;34:191-201.

24. Bhatia SP, McGinty D, Letizia CS, Api AM. Fragrance material review on 4-carvomenthenol. Food Chem Toxicol 2008;46:S914.

25. Bera P, Mukherjee C, Mitra A. Enzymatic production and emission of floral scent volatiles in Jasminum sambac. Plant Sci 2017;256:25-38. 